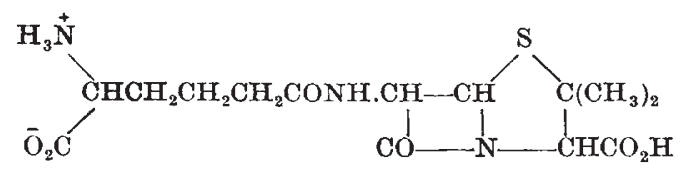

(X)

Cephalosporin $\mathrm{C}\left(\mathrm{C}_{16} \mathrm{H}_{21} \mathrm{O}_{8} \mathrm{~N}_{3} \mathrm{~S}\right)$ behaves like a penicillin in some respects but not in others. Like cephalosporin $\mathrm{N}$, it contains a residue of $\mathrm{D}-\alpha$-aminoadipic acid in the side-chain and has an absorption band in its infra-red spectrum characteristic of a penicillin. Unlike cephalosporin $\mathrm{N}$, it shows an absorption band $\left(\varepsilon_{\max } .9,000\right)$ at $260 \mathrm{~m} \mu$, is not inactivated by penicillinase and gives no penicillamine on hydrolysis with hot acid. However, DL-valine has been isolated from the hydrolysate of cephalosporin $\mathrm{C}$ treated with Raney nickel.

The papers of the symposium, with bibliographies, will be published by the Chemical Society as "Special Publication No. 5", which will include also an account of the discussions following each paper.

A. W. JoHnson

\title{
OBITUARIES
}

\section{Dr. Stanley Whitehead}

BY the death of Stanley Whitehead on May 5 at the early age of fifty-three, electrical engineering has lost one of its far-sighted leaders in the research field and the Electrical Research Association a director who has considerably widened its scope and activities. He entered Oxford with an open scholarship, where he took firsts in the Final School in Physics and Mathematical Moderations. In 1925 Whitehead accepted the post of physicist in the Electrical Research Association and proceeded to a part-time study of electrical engineering at East London (Queen Mary) College, which led in 1930 to a $\mathrm{Ph}$.D. and in 1952 to $\mathrm{a}$ D.Sc. degree of the University of London.

His early work with the Electrical Research Association led to the production of three critical surveys of dielectric phenomena covering breakdown phenomena in solid, liquid and gaseous dielectrics. This interest in dielectrics was maintained throughout his career and culminated in the monograph "Dielectric Breakdown of Solids" (Clarendon Press, Oxford, 1951), in which dielectric failure in all its aspects, for example, electronic breakdown, breakdown through thermal effects and by discharges in gaseous voids, was surveyed. His own theoretical researches on thermal breakdown and his experimental researches with colleagues on void discharges have proved useful contributions to knowledge. Problems of electrotechnical interest to which he has made contributions include those concerned with electrical transmission, cable ratings, and telephone and radio interference. During the Second World War he took a leading part, often at considerable personal risk, in the work of the Electrical Research Association on mine and bomb location.

Whitehead shouldered many responsibilities. He was chairman of the Science Abstracts Committee of the Institution of Electrical Engineers and a past chairman of the Measurements Section, honorary treasurer of the Institute of Physics, and a past vicepresident and chairman of the London Branch, a past joint-secretary of the Parliamentary and Scientific Committee, and the chairman of the Committee of Directors of Research Associations. He was the chairman of the governors of his old school, Sir Walter St. Johns, of Battersea, and a governor of Battersea Grammar School. But his interest in education did not stop there; many young graduates about to embark on a career in research received guidance, and often he was instrumental in securing for them financial support. One of the rewards accorded him in 1952 which gave him great pleasure was his fellowship of Queen Mary College.

Stanley Whitehead married in 1929 Mary Lyon Morehead; they had met at Oxford, where she too had a distinguished academic career, but on the classical side. There are two children of the marriage, a boy and a girl.

R. Davis

\section{Dr. T. Richards}

Taliesin RichaRds, senior lecturer in the Depart. ment of Microbiology, University of Reading, died on January 13 at the early age of forty-two, having been born on November 26,1913; his loss to the Department is great. Richards read chemistry at King's College, University of London, and obtained a B.Sc. with first-class honours in July 1936. He then entered the London School of Hygiene and Tropical Medicine to read for the postgraduate diploma in bacteriology, which he obtained in July 1937. Thus he entered the field of microbiology by postgraduate study, building upon a foundation of general chemistry a knowledge of microbial physiology and microbial forms and the techniques for studying them. He continued at the London School of Hygiene, doing research in the department of Prof. H. Raistrick, for which he obtained a Ph.D. in 1939 .

In September 1939 Richards was appointed independent lecturer in charge of the, then, Agricultural Bacteriology Laboratory in the Faculty of Agriculture, University of Reading, where students reading for the degree of B.Sc. in dairying received instruction in microbiology. Richards and his colleagues were also responsible for the course for the postgraduate diploma in general bacteriology (now discontinued). These courses owed much to Richards, who moulded them during the difficult war period and after. The experience gained in the design and teaching of these courses was of much value when later (March 1951) the laboratory was absorbed into a new Department of Microbiology in the Faculties of Science and of Agriculture. Richards was appointed senior lecturer in the new Department and continued to be particularly concerned with the courses for the B.Sc. (Dairying) degree. In planning the courses for the new degree subject of microbiology in the Faculty of Science, Richards's knowledge and experience were drawn upon to great advantage, and he himself did a considerable amount of teaching in these new courses. Richards was a good teacher and took much 
patient interest in the problems of students both in and out of the laboratory. He was much interested in student life in the University generally, and delighted in following the careers of his former students.

Richards's scientific interests covered a wide field in bacteriology. His papers included studies on the heat disinfection of Streptococcus faecalis, the development of media for the detection and enumeration of lipolytic micro-organisms, and the development of chemically defined media for classification in the coli-aerogenes group. $\mathrm{He}$ was an excellent microscopist and photographer. In spite of the difficult situation in the laboratories during the War and the later changes consequent on re-organization and development, Richards always managed to keep some personal research interests going, and to supervise a succession of research students.

Richards was an active member of the Society for Applied Bacteriology; he was elected to the committee in 1943, became an assistant editor of the Proceedings of the Society in 1945 and was its editor during 1948-50, until compelled by ill-health to resign. By then he had been able to carry out much work preparatory to the appearance of the Journal of Applied Bacteriology, and he continued until his death to give valuable assistance to his editorial successors. Richards was an active member of the Association of University Teachers and was for two years a Central Council representative of the University of Reading branch. He leaves a widow and two sons.
B. C. J. G. KNIGHT

\section{NEWS and VIEWS}

\section{The Queen's Birthday Honours}

THE following names of scientists and others associated with scientific work appear in the Queen's Birthday Honours list :

Viscount : Lord Cherwell, lately Dr. Lee's professor of experimental philosophy in the University of Oxford, for public services.

Barons : Sir Henry Cohen, professor of medicine in the University of Liverpool, for services to medicine; Sir Ronald Weeks, chairman of the National Advisory Council for Education in Industry and Commerce, and president of the British Scientific Instrument Research Association.

$O . M$. : Lord Hailey.

K.C.B. : Sir Gordon Radley, director-general of the General Post Office.

K.B.E. : Lord Glentanar, member of the Scottish Agricultural Advisory Council ; Edmund G. Harwood, deputy secretary, Ministry of Agriculture, Fisheries and Food; Hugh N. Hume, deputy chairman, Colonial Development Corporation, and for other public services; Sir Thomas Merton, treasurer of the Royal Society.

Knights : Prof. Samuel P. Bedson, emeritus professor of bacteriology, University of London; Prof. Harry G. Champion, professor of forestry, University of Oxford ; Prof. William J. Pugh, director of the Geological Survey of Great Britain and the Museum of Practical Geology (Department of Scientific and Industrial Research); Allan S. Quartermaine, president during 1951-52 of the Institution of Civil Engineers; John F. Wolfenden, vice-chancellor of the University of Reading.

C.B. : J. Anderson, chief scientist, Admiralty Signal and Radar Establishment, Portsdown, Cosham, Hants ; H. S. Gilham, assistant comptroller, Patent Office (Board of Trade); J. I. Magowan, lately permanent secretary, Ministry of Agriculture, Northern Ireland.

C.M.G.: D. H. Black, chief scientific officer, Ministry of Supply; Dr. C. E. Lucas, director of marine and freshwater fishery research, Scottish Home Department.

C.B.E. : C. B. Bisset, director of the Geological Survey, Tanganyika; L. Boddington, deputy chief scientific officer, Ministry of Supply; Dr. F. P. Bowden, reader in physical chemistry, University of Cambridge ; R. M. Currie, head of the Work Study Department, Imperial Chemical Industries, Ltd.;
J. R. V. Dolphin, chief engineer, Atomic Weapons Research Establishment, United Kingdom Atomic Energy Authority; A. S. Fortune, chief inspector, Department of Agriculture for Scotland; E. T. Green, for services to agriculture in Northern Ireland; Dr. P. D'Arcy Hart, director of the Tuberculosis Research Unit, Medical Research Council; G. V. B. Herford, deputy chief scientific officer, Pest Infestation Laboratory (Department of Scientific and Industrial Research); A. B. Mann, chief mechanical and electrical engineer, Ministry of Works; Prof. K. Mather, professor of genetics, University of Birmingham; J. E. Peat, deputy senior officer, Empire Cotton Growing Corporation, Tanganyika; J. D. Peattie, chief engineer, Central Electricity Authority; S. P. Peters, deputy director (forecasting), Meteorological Office (Air Ministry); G. Williamson, principal of the Veterinary School, Federation of Nigeria; F. N. Woodward, director of the Institute of Seaweed Research.

I.S.O. : J. F. Sinclair, principal, Ministry of Agriculture, Fisheries and Food; R. I. Wells, principal scientific officer, Air Ministry.

\section{Directorship of the Science Museum, London: Dr. T. C. S. Morrison-Scott}

DR. T. C. S. Morrison-ScotT, a principal scientific officer in the British Museum (Natural History), has been appointed director of the Science Museum, London, in succession to the late Dr. F. Sherwood Taylor. Dr. Morrison-Scott was born in 1908; he went to Christchurch, Oxford, where he read history and law, and later to the Imperial College of Science and Technology, where he graduated with first-class honours in zoology in 1935. After a period as a biology master at Eton, he became a research student at the Zoological Society of London, and joined the British Museum (Natural History) in 1936. During the Second World War, he served with the R.N.V.R., and was awarded the Distinguished Service Cross. During the earlier part of his career Dr. Morrison-Scott was mainly interested in ecology in relation to evolution. At the British Museum he was assigned to the Mammal Section of the Zoological Department, under M. A. C. Hinton, and ultimately he assumed charge of that section. After the War he also became the officer in charge of the Tring Museum. His research work has covered a wide range of mammalian topics from 